\title{
Characterization and comparison of transgenic Artemisia annua GYR and wild-type NON-GYR plants in an environmental release trial
}

\author{
H. Liu ${ }^{1,2}$, G.G. Wu ${ }^{2}$, J.B. Wang ${ }^{1}$, X. Wu $u^{3}$, L. Bai ${ }^{1,2}$, W. Jiang ${ }^{3}$, B.B. Lv ${ }^{3}$, \\ A.H. Pan ${ }^{2,3}$, J.W. Jia ${ }^{3}$, P. Li ${ }^{2}$, K. Zhao ${ }^{2}$, L.X. Jiang ${ }^{1}$ and X.M. Tang ${ }^{1,3}$ \\ ${ }^{1}$ Biotechnology Research Institute, Shanghai Academy of Agriculture Sciences, \\ Shanghai, China \\ ${ }^{2}$ Supervision, Inspection and Test Center for Environmental Safety of GM \\ Crops of MOA, Shanghai, China \\ ${ }^{3}$ Key Laboratory of Agricultural Genetics and Breeding, Shanghai, China \\ Corresponding author: X.M. Tang \\ E-mail: saas_xmtang@foxmail.com \\ Genet. Mol. Res. 15 (3): gmr.15038273 \\ Received December 15, 2015 \\ Accepted June 2, 2016 \\ Published August 26, 2016 \\ DOI http://dx.doi.org/10.4238/gmr.15038273
}

Copyright (C) 2016 The Authors. This is an open-access article distributed under the terms of the Creative Commons Attribution ShareAlike (CC BY-SA) 4.0 License.

\begin{abstract}
The anti-malarial drug, artemisinin, is quite expensive as a result of its slow content in Artemisia annua. Recent investigations have suggested that genetic engineering of $A$. апnиа is a promising approach to improve the yield of artemisinin. In this study, the transgenic A. annua strain GYR, which has high artemisinin content, was evaluated in an environmental release trial. First, GYR plants were compared with the wild-type variety NON-GYR, with regard to phenotypic characters (plant height, crown width, stem diameter, germination rate, leaf dry weight, 1000-seed weight, leave shape). Second, stress resistance in the two varieties (salt, drought, herbicide, and cold resistance) was evaluated under different experimental conditions. Finally, gene
\end{abstract}


flow was estimated. The results indicated that there were significant differences in several agronomic traits (plant height, stem diameter, and leave dry weight) between the transgenic GYR and NON-GYR plants. Salt stress in transgenic and control plants was similar, except under high $\mathrm{NaCl}$ concentrations $(1.6 \%, \mathrm{w} / \mathrm{w})$. Leaf water, proline, and MDA content (increased significantly) were significantly different. Transgenic A. апnиa GYR plants did not grow better than NONGYR plants with respect to drought and herbicide resistance. The two varieties maintained vitality through the winter. Third, gene flow was studied in an environmental risk trial for transgenic GYR. The maximum gene flow frequency was $2.5 \%$, while the maximum gene flow distance was $24.4 \mathrm{~m}$; gene flow was not detected at $29.2 \mathrm{~m}$ at any direction. Our findings may provide an opportunity for risk assessment in future commercialization of transgenic A. annua varieties.

Key words: Artemisia annua; GYR; Phenotypic characterization; Stress resistance; Gene flow

\section{INTRODUCTION}

According to the latest estimates, 198 million cases of malaria occurred globally in 2013 (uncertainty range: 124-283 million), resulting in 584,000 deaths (uncertainty range: 367,000-755,000). The disease burden is heaviest in the World Health Organization (WHO) African Region, where an estimated $90 \%$ of all deaths from malaria occur, and in children aged $<5$ years, who account for $78 \%$ of all malaria deaths (http://www.who.int/en/). Artemisinin, a sesquiterpene isolated from Artemisia annua, is currently the most effective therapeutic agent against both drug-resistant and cerebral malaria-causing strains of Plasmodium falciparum (Qinghaosu Antimalaria Coordinating Research Group, 1979a,b; Weathers et al., 2006). However, the artemisinin content in A. annua is very low, and the synthesis of artemisinin is both difficult and costly; therefore, genetic engineering is considered as an alternative tool to increase the content of artemisinin in A. annua.

Transgenic A. аппиа GYR was obtained previously through Agrobacterium tumefaciens-mediated transformations in Kexuan Tang's Lab. Transgenic varieties of GYR were developed to enhance the expression of amorpha-4,11-diene synthase (ADS), cytochrome P450-dependent hydroxylase (CYP71AV1), and cytochrome P450 oxidoreductase $(C P R)$ genes in $A$. annua, which are the three key enzymes catalyzing artemisinin biosynthesis (Lu et al., 2013). However, the cultivation of genetically modified (GM) plants has raised concerns of potential ecological and human health risks (Conner et al., 2003; Romeis et al., 2008; Hutchison et al., 2010), and many questions remain unanswered with regard to the environmental release and commercialization of GM plants. Therefore, applications for the deliberate release of a new transgenic plant are required to be submitted to regulatory authorities in the European Union, the United Kingdom, Japan, the United States, and China. In China, the Ministry of Agriculture (MOA) implemented GMO (genetically modified organisms) regulations in 1996 (Jia and Peng, 2002). All applications for biosafety assessments related to experimental research, field trials, and environmental release are required to be evaluated by the GMO Biosafety Committee before commercialization. To date, many transgenic plants

Genetics and Molecular Research 15 (3): gmr.15038273 
have been tested in field trials, and some have been grown commercially; however, no study has evaluated transgenic $A$. апnиa in an environmental release trial, with the exception of transgenic $A$. апnua ADA, SQS, GFH in our laboratory (Jiang et al., 2010b).

In this study, phenotypic characters (plant height, crown width, stem diameter, germination rate, leave dry weight, 1000-seed weight, and shape of leaves) of transgenic GYR and wild-type NON-GYR plants were investigated. Stress resistance (salt, drought, herbicide, and cold resistance) was compared between the two strains. Next, gene flow was estimated as an important parameter in the field trial. The results of this study provide useful data for risk assessments in the future commercialization of transgenic A. annua varieties.

\section{MATERIAL AND METHODS}

\section{Plant materials}

The transgenic $A$. апnи G GYR variety used in this study was kindly provided by Prof. Kexuan Tang from Shanghai Jiaotong University. The A. tumefaciens-mediated transformation of $A$. annua collected from Chongqing (a municipality in Southwest China) was established by Prof. Tang's laboratory (Wang et al., 2012), and the wild-type $A$. annua NON-GYR was used as a control. After transformation, expression of CYP71AV1 and CPR was found to be enhanced in the GYR plants (Figure 1). The two over-expressed genes can significantly improve the content of artemisinin.

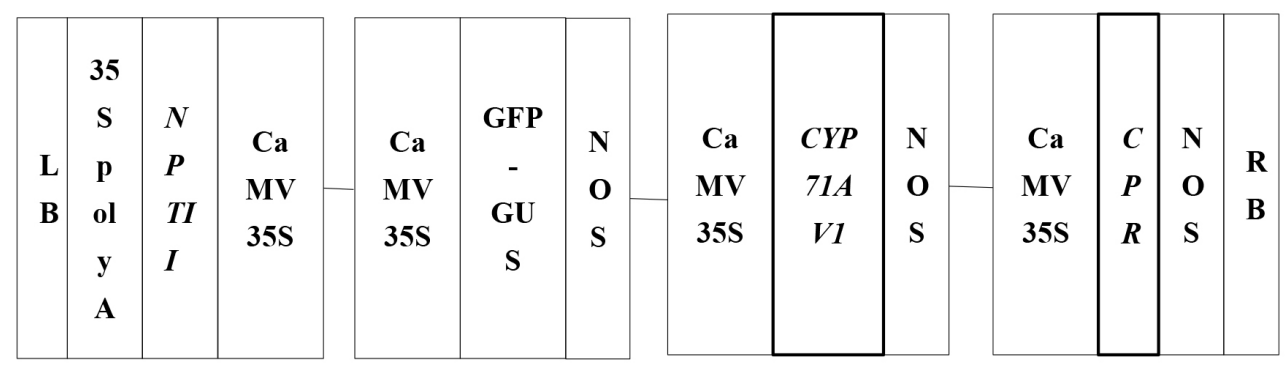

Figure 1. Construction diagram of the binary expression vector, pb2300-GYR.

\section{Field location}

The transgenic A. апnиa GYR and NON-GYR plants were cultivated in the White Crane field station of the Shanghai Academy of Agricultural Sciences, which is authorized by the MOA, China, for environmental risk assessments of transgenic plants. The field station is located in the northwestern part of Shanghai City. It has a subtropical monsoon climate, distinct seasons, full sunshine with abundant rainfall, and is suitable for the growth of $A$. annua plants. There are concrete walls around the field station to ensure isolation. The greenhouse part of the trial was performed in the Supervision, Inspection, and Test Center for Environmental Safety of GM Crops of MOA (Shanghai), and the temperature was maintained at $25^{\circ} \mathrm{C}$. Medium soil contains organic matter, vermiculite, and perlite at a 7:2:1 ratio. There are no other GM plants in the greenhouse. The entire experiment was supervised by a security guard, and all GM material was burned at the end of the trial.

Genetics and Molecular Research 15 (3): gmr.15038273 


\section{Experimental design}

In accordance with regulations on safety assessments of GMOs in China, $A$. апnиа was first planted in a rectangular plot, covering an area of about 0.3 ha (Guidelines for the Safety Assessment of Transgenic Plants, China, 2007) with a length of $100 \mathrm{~m}$ and a width of $30 \mathrm{~m}$. Non-transgenic maize was planted around each plot to isolate the GYR and NON-GYR. All plants were cultivated according to routine practices in the corresponding region (Figure 2), with approximately 2304 plants per plot (1.25 m between rows).

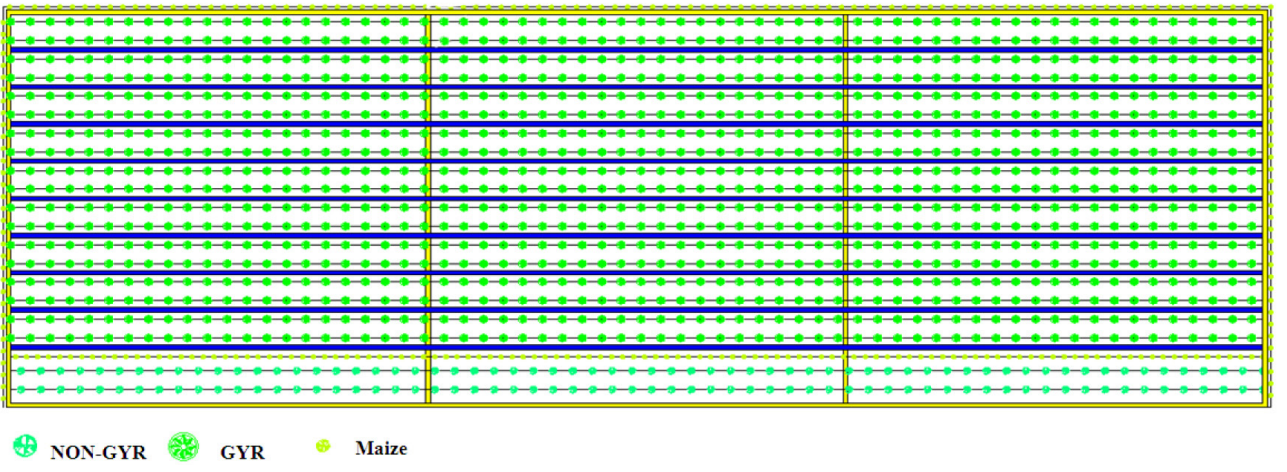

Figure 2. Cultivation schematic for GYR environmental release trial.

\section{Transplant survival}

The transgenic $A$. апnиa GYR and NON-GYR plants were grown in plots in a growth chamber for 2 months, and were then transplanted and grown in the field. After transplantation, the number of dead seedlings was calculated.

\section{Phenotypic characterization}

Three months after transplantation, the growth and morphology of transgenic $A$. annua GYR and NON-GYR plants, such as plant height, crown width, stem diameter, germination rate, one-leaf dry weight, 1000-seed weight, and shape of leaves were compared.

\section{Plant height, crown width, stem diameter}

In field tests of $A$. апnиа, a complete stochastic region design of single factor was applied. A total of $40 \mathrm{~A}$. annua strains were randomly selected from each block and used to determine plant height, crown width, and stem diameter in the early and mid-stages of vegetative growth (June 18 and July 16, respectively).

\section{Germination rate}

The seeds of two A. апnиa varieties were carefully husked, washed with detergent, and rinsed thoroughly with distilled water. One hundred seeds of each variety were sown in trays loaded with aseptic mixed vermiculite soil (soil:verimiculite:perlite, 7:3:1). Another 100

Genetics and Molecular Research 15 (3): gmr.15038273 
seeds were sown in distilled water, and a further 100 seeds were sown in sterile medium. After 7 days at $25^{\circ} \mathrm{C}$, the germination rate of each variety was calculated using the equation below:

Seed germination rate $(\%)=($ number of seeds germinated $/$ number of full seeds $) \times 100$.

\section{Leaf dry weight}

Ten leaves on the top of the plant at the blossom stage were randomly picked, then placed in an oven at $105^{\circ} \mathrm{C}$ for $0.5 \mathrm{~h}$ to inactivate the enzymes. Finally, leaves were dried to a constant weight at $70^{\circ} \mathrm{C}$ and the dry weights were recorded; this was repeated three times (Shi et al., 2010).

\section{Thousand-seed weight}

To compare seed morphology, seeds were harvested from one spike in the year before the environmental release trial. Because the seeds of $A$. аппиа are too small to collect, the flowers of 30 plants were bagged and their seeds were subsequently collected from the bags. The 1000-seed weight of each variety was measured based on the seeds harvested from 30 individual plants.

\section{Stress resistance}

The resistance experiments were conducted in sunlight in a greenhouse.

\section{Salt stress}

Salt stress experiments were initiated with 5-week-old plants. $\mathrm{NaCl}$ was added to the nutrient solution at concentrations of $0,0.4,0.8,1.2$, and $1.6 \%(\mathrm{w} / \mathrm{w})$. After 9 days, the relative water content of leafs from the stressed groups (six plants per group) was measured as follows:

leaf relative water content $(\%)=[($ fresh weight - dry weight $) /$ fresh weight $]$ x 100 (Lai and Lui, 1988).

Peroxidase (POD) activity, free proline, and malondialdehyde contents were also measured (Hunting et al., 1959; Lei et al., 2007; Summart et al., 2010).

\section{Drought stress}

Five-week-old plants were used to evaluate the effects of drought stress. PEG 6000 was added to the nutrient solution to induce drought stress. PEG 6000 molecules are too large to be taken up by intact plant roots (Lawlor, 1970), thus imposing uniform and controllable drought stress. Six plants from each $A$. апnиa variety were stressed with PEG 6000 at concentrations of $0,50,100$, and $150 \mathrm{~g} / \mathrm{L}$. The free proline contents, plant height yield, and compound leaf difference of drought-stressed plants were determined.

\section{Herbicide tolerance}

Two different herbicides were purchased from Syngenta Co. (Shanghai, China): the non-selective herbicide paraquat; and the selective herbicide metolachlor. Paraquat was

Genetics and Molecular Research 15 (3): gmr.15038273 
sprayed on 5-week-old plants, and metolachlor was sprayed 3 days after the seeds of GYR and NON-GYR were sown, according to the supplier instructions. The plants were observed 14 days later.

\section{Wintering ability}

The two different kinds of seeds were sown outdoors in winter (minimum temperature $-8^{\circ} \mathrm{C}$ ), and the survival rate of next-generation seedlings and survival competitiveness in winter were compared.

\section{Gene flow}

Gene flow was investigated in $80-\mathrm{m}$ long, $35-\mathrm{m}$ wide rectangular plots during the period from May 2010 to May 2011 (Figure 3). A. аппиa GYR was cultivated in five concentric circles (marked in red) with an increase of $1.2 \mathrm{~m}$ in radius from inside to outside. The remaining area was used to plant $A$. аппиа NON-GYR plants. When $A$. annua was planted, corn was planted around the experimental field to act as an isolation zone.

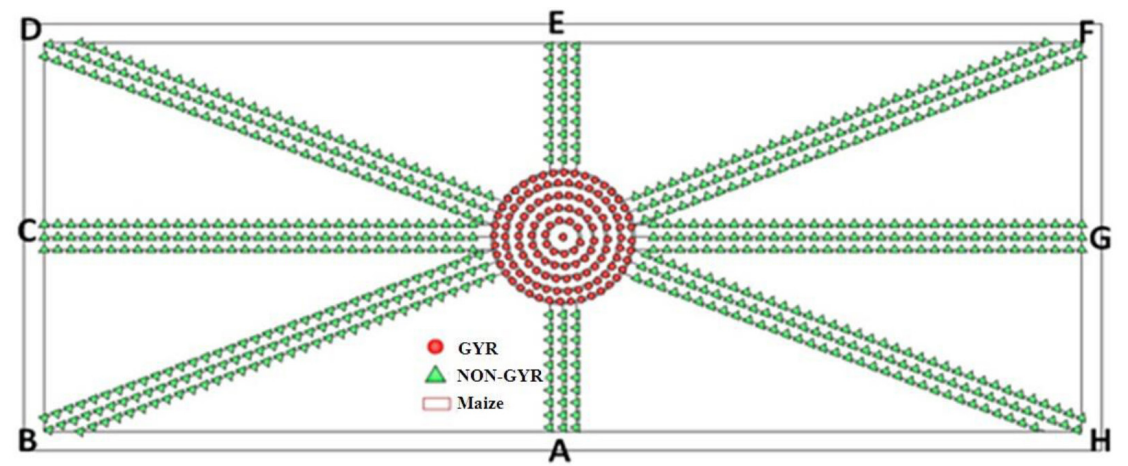

Figure 3. Planting diagram. A. S: south; B. SW: southwest; C. W: west: D. NW: northwest; E. N: north; F. NE: northeast; G. E: east; H. SE: southeast.

In total, the experiment involved 98 pilot sites, with 14 sites in each direction: Sites 1-5 were marked at intervals of $0.8 \mathrm{~m}$; sites 6-10 had 2.4-m intervals; and sites 11-14 had 4.8$\mathrm{m}$ intervals. Seeds were harvested from every site (Table 1). A. annua seeds were harvested at the bottom, middle, and lower parts of the plants. Finally, seeds harvested at each point were mixed and taken to the lab for subsequent analysis.

\section{Determination of germination rate}

One hundred seeds were randomly collected from pilot sites and germinated in culture vessels. This was repeated three times. SPSS16.0 was adapted for data analysis after 10 days (Table 2).

Genetics and Molecular Research 15 (3): gmr.15038273 


\section{Table 1. Planting distance of NON-GYR.}

\begin{tabular}{|c|c|c|c|c|c|c|c|c|c|c|c|c|c|c|}
\hline \multirow{3}{*}{$\begin{array}{l}\text { Direction } \\
\text { South }\end{array}$} & \multicolumn{5}{|c|}{$0.8-\mathrm{m}$ interval } & \multicolumn{5}{|c|}{ 2.4-m interval } & \multicolumn{4}{|c|}{ 4.8-m interval } \\
\hline & A-1 & A-2 & A-3 & A-4 & A-5 & A-6 & A-7 & A-8 & & & & & & \\
\hline & 6.8 & 7.6 & 8.4 & 9.2 & 10 & 12.4 & 14.8 & 17.2 & & & & & & \\
\hline \multirow{2}{*}{ Southwest } & B-1 & B-2 & B-3 & B-4 & B-5 & B-6 & B-7 & B-8 & B-9 & B-10 & B-11 & B-12 & B-13 & B-14 \\
\hline & 6.8 & 7.6 & 8.4 & 9.2 & 10 & 12.4 & 14.8 & 17.2 & 19.6 & 24.4 & 29.2 & 34 & 38.8 & 43.6 \\
\hline \multirow[t]{2}{*}{ West } & $\mathrm{C}-1$ & $\mathrm{C}-2$ & $\mathrm{C}-3$ & $\mathrm{C}-4$ & $\mathrm{C}-5$ & $\mathrm{C}-6$ & $\mathrm{C}-7$ & $\mathrm{C}-8$ & C-9 & $\mathrm{C}-10$ & $\mathrm{C}-11$ & $\mathrm{C}-12$ & $\mathrm{C}-13$ & \\
\hline & 6.8 & 7.6 & 8.4 & 9.2 & 10 & 12.4 & 14.8 & 17.2 & 19.6 & 24.4 & 29.2 & 34 & 38.8 & \\
\hline \multirow[t]{2}{*}{ Northwest } & D-1 & D-2 & D-3 & D-4 & D-5 & D-6 & D-7 & D-8 & D-9 & D-10 & D-11 & D-12 & D-13 & D-14 \\
\hline & 6.8 & 7.6 & 8.4 & 9.2 & 10 & 12.4 & 14.8 & 17.2 & 19.6 & 24.4 & 29.2 & 34 & 38.8 & 43.6 \\
\hline \multirow[t]{2}{*}{ North } & E-1 & E-2 & E-3 & E-4 & E-5 & E-6 & E-7 & E-8 & & & & & & \\
\hline & 6.8 & 7.6 & 8.4 & 9.2 & 10 & 12.4 & 14.8 & 17.2 & & & & & & \\
\hline \multirow[t]{2}{*}{ Northeast } & F-1 & F-2 & $\mathrm{F}-3$ & $\mathrm{~F}-4$ & F-5 & F-6 & F-7 & $\mathrm{F}-8$ & F-9 & F-10 & F-11 & F-12 & F-13 & F-14 \\
\hline & 6.8 & 7.6 & 8.4 & 9.2 & 10 & 12.4 & 14.8 & 17.2 & 19.6 & 24.4 & 29.2 & 34 & 38.8 & 43.6 \\
\hline \multirow[t]{2}{*}{ East } & G-1 & G-2 & G-3 & G-4 & G-5 & G-6 & G-7 & G-8 & G-9 & G-10 & G-11 & G-12 & G-13 & \\
\hline & 6.8 & 7.6 & 8.4 & 9.2 & 10 & 12.4 & 14.8 & 17.2 & 19.6 & 24.4 & 29.2 & 34 & 38.8 & \\
\hline \multirow[t]{2}{*}{ Southeast } & H-1 & $\mathrm{H}-2$ & $\mathrm{H}-3$ & $\mathrm{H}-4$ & $\mathrm{H}-5$ & H-6 & $\mathrm{H}-7$ & H-8 & H-9 & $\mathrm{H}-10$ & $\mathrm{H}-11$ & $\mathrm{H}-12$ & H-13 & $\mathrm{H}-14$ \\
\hline & 6.8 & 7.6 & 8.4 & 9.2 & 10 & 12.4 & 14.8 & 17.2 & 19.6 & 24.4 & 29.2 & 34 & 38.8 & 43.6 \\
\hline
\end{tabular}

S: south; SW: southwest; W: west; NW: northwest; N: north; NE: northeast; E: east; SE: southeast.

Table 2. Germination rate of the every planting point.

\begin{tabular}{|c|c|c|c|c|c|c|c|c|c|c|c|c|c|c|c|}
\hline Direction & \multicolumn{5}{|c|}{0.8 -m interval } & \multicolumn{5}{|c|}{ 2.4-m interval } & \multicolumn{4}{|c|}{4.8 - $\mathrm{m}$ interval } & Means \\
\hline \multirow{2}{*}{ South } & A-1 & A-2 & A-3 & A-4 & A-5 & A-6 & A-7 & A-8 & & & & & & & \multirow[t]{2}{*}{$83.7 \%$} \\
\hline & $85.6 \%$ & $72.7 \%$ & $84.5 \%$ & $88.9 \%$ & $84.6 \%$ & $81.2 \%$ & $85.6 \%$ & $86.3 \%$ & & & & & & & \\
\hline \multirow[t]{2}{*}{ Southwest } & B-1 & B-2 & B-3 & B-4 & B-5 & B-6 & B-7 & B-8 & B-9 & B-10 & B-11 & B-12 & B-13 & B-14 & \multirow[t]{2}{*}{$87.1 \%$} \\
\hline & $84.6 \%$ & $90.6 \%$ & $87.6 \%$ & $79.8 \%$ & $85.6 \%$ & $92.3 \%$ & $87.4 \%$ & $90.5 \%$ & $79.8 \%$ & $91.0 \%$ & $88.6 \%$ & $90.2 \%$ & $88.7 \%$ & $82.5 \%$ & \\
\hline \multirow[t]{2}{*}{ West } & $\mathrm{C}-1$ & $\mathrm{C}-2$ & C-3 & C-4 & $\mathrm{C}-5$ & C-6 & C-7 & C-8 & C-9 & C-10 & $\mathrm{C}-11$ & $\mathrm{C}-12$ & $\mathrm{C}-13$ & & \multirow[t]{2}{*}{$84.5 \%$} \\
\hline & $85.6 \%$ & $89.5 \%$ & $87.8 \%$ & $82.6 \%$ & $79.8 \%$ & $69.8 \%$ & $79.4 \%$ & $87.9 \%$ & $90.2 \%$ & $88.6 \%$ & $84.1 \%$ & $84.9 \%$ & $87.8 \%$ & & \\
\hline \multirow[t]{2}{*}{ Northwest } & D-1 & D-2 & D-3 & D-4 & D-5 & D-6 & D-7 & D-8 & D-9 & D-10 & D-11 & D-12 & D-13 & D-14 & \multirow[t]{2}{*}{$79.3 \%$} \\
\hline & $81.6 \%$ & $80.7 \%$ & $82.3 \%$ & $75.9 \%$ & $75.5 \%$ & $85.1 \%$ & $65.8 \%$ & $85.9 \%$ & $85.7 \%$ & $80.2 \%$ & $83.4 \%$ & $75.6 \%$ & $69.8 \%$ & $82.8 \%$ & \\
\hline \multirow[t]{2}{*}{ North } & E-1 & E-2 & E-3 & E-4 & E-5 & E-6 & E-7 & E-8 & & & & & & & \multirow[t]{2}{*}{$81.3 \%$} \\
\hline & $90.5 \%$ & $80.6 \%$ & $85.3 \%$ & $75.9 \%$ & $90.9 \%$ & $83.7 \%$ & $74.6 \%$ & $68.9 \%$ & & & & & & & \\
\hline \multirow[t]{2}{*}{ Northeast } & F-1 & $\mathrm{F}-2$ & F-3 & F-4 & F-5 & F-6 & F-7 & F-8 & F-9 & F-10 & F-11 & F-12 & F-13 & F-14 & \multirow[t]{2}{*}{$80.7 \%$} \\
\hline & $83.1 \%$ & $76.8 \%$ & $77.6 \%$ & $81.5 \%$ & $79.8 \%$ & $91.5 \%$ & $85.1 \%$ & $69.7 \%$ & $77.9 \%$ & $84.9 \%$ & $82.3 \%$ & $84.5 \%$ & $69.1 \%$ & $86.4 \%$ & \\
\hline \multirow[t]{2}{*}{ East } & G-1 & G-2 & G-3 & G-4 & G-5 & G-6 & G-7 & G-8 & G-9 & G-10 & G-11 & G-12 & G-13 & & \multirow[t]{2}{*}{$83.2 \%$} \\
\hline & $87.2 \%$ & $77.5 \%$ & $73.8 \%$ & $89.8 \%$ & $82.7 \%$ & $90.7 \%$ & $90.8 \%$ & $84.7 \%$ & $82.4 \%$ & $84.5 \%$ & $85.7 \%$ & $82.7 \%$ & $68.7 \%$ & & \\
\hline \multirow[t]{2}{*}{ Southeast } & H-1 & H-2 & $\mathrm{H}-3$ & $\mathrm{H}-4$ & $\mathrm{H}-5$ & H-6 & $\mathrm{H}-7$ & H-8 & H-9 & H-10 & H-11 & H-12 & $\mathrm{H}-13$ & H-14 & \multirow[t]{2}{*}{$81.5 \%$} \\
\hline & $86.4 \%$ & $77.8 \%$ & $78.5 \%$ & $74.6 \%$ & $74.8 \%$ & $89.4 \%$ & $69.7 \%$ & $79.8 \%$ & $93.4 \%$ & $79.2 \%$ & $85.7 \%$ & $88.4 \%$ & $84.5 \%$ & $79.3 \%$ & \\
\hline
\end{tabular}

\section{Kanamycin resistance}

A total of 100 strains randomly selected at each test point were planted on $1 / 2$ Murashige and Skoog (MS) media with kanamycin after the seeds had germinated (Table 3). The number of surviving plants was recorded and samples were subsequently subjected to molecular identification.

\section{Molecular identification by PCR}

The surviving kanamycin-resistant plants were moved to pots. Then, 3-5 leaves were picked from each seedling after 20-day growth for DNA extraction (Table 4 and Figure 4). 
Table 3. Survival rate of Artemisia annua on the medium containing kanamycin.

\begin{tabular}{|c|c|c|c|c|c|c|c|c|c|c|c|c|c|c|}
\hline \multirow{3}{*}{$\begin{array}{l}\text { Direction } \\
\text { South }\end{array}$} & \multicolumn{5}{|c|}{0.8 - $\mathrm{m}$ interval } & \multicolumn{5}{|c|}{ 2.4-m interval } & \multicolumn{4}{|c|}{ 4.8-m interval } \\
\hline & A-1 & A-2 & A-3 & A-4 & A-5 & A-6 & A-7 & A-8 & & & & & & \\
\hline & 11 & 41 & 18 & 19 & 15 & 10 & 11 & 8 & & & & & & \\
\hline \multirow[t]{2}{*}{ Southwest } & B-1 & B-2 & B-3 & B-4 & B-5 & B-6 & B-7 & B-8 & B-9 & B-10 & B-11 & B-12 & B-13 & $\overline{B-14}$ \\
\hline & 14 & 17 & 28 & 34 & 26 & 13 & 14 & 21 & 8 & 11 & 8 & 14 & 7 & 6 \\
\hline \multirow[t]{2}{*}{ West } & $\mathrm{C}-1$ & $\mathrm{C}-2$ & C-3 & C-4 & $\mathrm{C}-5$ & C-6 & C-7 & C-8 & C-9 & C-10 & C-11 & C-12 & $\mathrm{C}-13$ & \\
\hline & 28 & 32 & 27 & 25 & 13 & 19 & 10 & 11 & 16 & 12 & 7 & 10 & 8 & \\
\hline \multirow[t]{2}{*}{ Northwest } & D-1 & D-2 & D-3 & D-4 & D-5 & D-6 & D-7 & D-8 & D-9 & D-10 & D-11 & D-12 & D-13 & D-14 \\
\hline & 26 & 24 & 31 & 20 & 18 & 10 & 27 & 18 & 15 & 11 & 10 & 8 & 2 & 6 \\
\hline \multirow[t]{2}{*}{ North } & E-1 & E-2 & E-3 & E-4 & E-5 & E-6 & E-7 & E-8 & & & & & & \\
\hline & 22 & 23 & 12 & 11 & 6 & 8 & 13 & 10 & & & & & & \\
\hline \multirow[t]{2}{*}{ Northeast } & F-1 & F-2 & F-3 & F-4 & F-5 & F-6 & F-7 & F-8 & F-9 & F-10 & F-11 & F-12 & F-13 & $\overline{F-14}$ \\
\hline & 26 & 30 & 29 & 14 & 16 & 27 & 17 & 13 & 14 & 8 & 11 & 10 & 8 & 3 \\
\hline \multirow[t]{2}{*}{ East } & G-1 & G-2 & G-3 & G-4 & G-5 & G-6 & G-7 & G-8 & G-9 & G-10 & G-11 & G-12 & G-13 & \\
\hline & 18 & 21 & 14 & 3 & 22 & 17 & 13 & 16 & 4 & 13 & 10 & 16 & 8 & \\
\hline \multirow[t]{2}{*}{ Southeast } & $\mathrm{H}-1$ & $\mathrm{H}-2$ & H-3 & H-4 & H-5 & H-6 & H-7 & H-8 & H-9 & H-10 & H-11 & H-12 & H-13 & H-14 \\
\hline & 29 & 26 & 17 & 25 & 18 & 14 & 9 & 17 & 22 & 8 & 10 & 7 & 1 & 9 \\
\hline
\end{tabular}

Table 4. Positive detection distance of the every planting point.

\begin{tabular}{|c|c|c|c|c|c|c|c|c|c|c|c|c|c|c|}
\hline \multirow{3}{*}{$\begin{array}{l}\text { Direction } \\
\text { South }\end{array}$} & \multicolumn{5}{|c|}{0.8 - $\mathrm{m}$ interval } & \multicolumn{5}{|c|}{ 2.4-m interval } & \multicolumn{4}{|c|}{$4.8-\mathrm{m}$ interval } \\
\hline & A-1 & A-2 & A-3 & A-4 & A-5 & A-6 & A-7 & A-8 & & & & & & \\
\hline & 4 & 1 & 0 & 1 & 0 & 1 & 0 & 0 & & & & & & \\
\hline \multirow[t]{2}{*}{ Southwest } & B-1 & B-2 & B-3 & B-4 & B-5 & B-6 & B-7 & B-8 & B-9 & B-10 & B-11 & B-12 & B-13 & B-14 \\
\hline & 3 & 0 & 1 & 3 & 0 & 1 & 1 & 0 & 0 & 0 & 0 & 0 & 0 & 0 \\
\hline \multirow[t]{2}{*}{ West } & $\mathrm{C}-1$ & $\mathrm{C}-2$ & $\mathrm{C}-3$ & C-4 & $\mathrm{C}-5$ & C-6 & C-7 & $\mathrm{C}-8$ & C-9 & C-10 & $\mathrm{C}-11$ & C-12 & C-13 & \\
\hline & 5 & 4 & 2 & 0 & 1 & 0 & 1 & 0 & 0 & 1 & 0 & 0 & 0 & \\
\hline \multirow[t]{2}{*}{ Northwest } & D-1 & $\mathrm{D}-2$ & D-3 & D-4 & D-5 & D-6 & D-7 & D-8 & D-9 & D-10 & D-11 & D-12 & D-13 & D-14 \\
\hline & 2 & 1 & 0 & 0 & 0 & 1 & 0 & 1 & 0 & 0 & 0 & 0 & 0 & 0 \\
\hline \multirow[t]{2}{*}{ North } & E-1 & E-2 & E-3 & E-4 & E-5 & E-6 & E-7 & E-8 & & & & & & \\
\hline & 1 & 1 & 0 & 1 & 0 & 0 & 0 & 0 & & & & & & \\
\hline \multirow[t]{2}{*}{ Northeast } & F-1 & F-2 & F-3 & $\mathrm{F}-4$ & F-5 & F-6 & F-7 & F-8 & F-9 & F-10 & F-11 & F-12 & F-13 & F-14 \\
\hline & 2 & 0 & 1 & 0 & 1 & 0 & 0 & 0 & 0 & 0 & 0 & 0 & 0 & 0 \\
\hline \multirow[t]{2}{*}{ East } & G-1 & G-2 & G-3 & G-4 & G-5 & G-6 & G-7 & G-8 & G-9 & G-10 & G-11 & G-12 & G-13 & \\
\hline & 1 & 1 & 0 & 0 & 0 & 0 & 0 & 0 & 0 & 0 & 0 & 0 & 0 & \\
\hline \multirow[t]{2}{*}{ Southeast } & $\mathrm{H}-1$ & H-2 & H-3 & $\mathrm{H}-4$ & $\mathrm{H}-5$ & H-6 & H-7 & H-8 & H-9 & H-10 & H-11 & H-12 & H-13 & H-14 \\
\hline & 2 & 2 & 1 & 0 & 0 & 0 & 1 & 0 & 0 & 0 & 0 & 0 & 0 & 0 \\
\hline
\end{tabular}

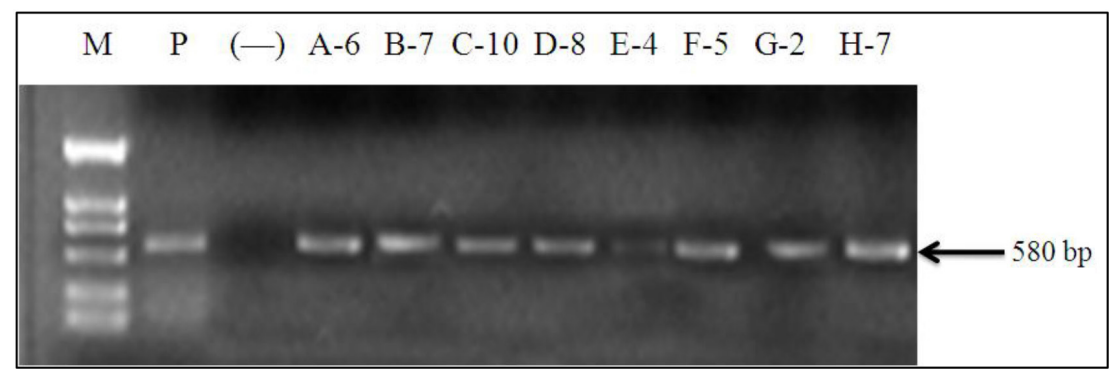

Figure 4. Detected positive points as electrophoresis pattern.

\section{Statistical analysis}

All data were compared and analyzed using the independent-sample $t$-test in the SPSS 16.0 and GraphPadPrism v5.0 software.

Genetics and Molecular Research 15 (3): gmr.15038273 


\section{RESULTS}

Previously, genes involved in the artemisinin biosynthetic pathway that are essential for increasing the artemisinin content in A. аппиа have been over-expressed by genetic engineering. However, it is unknown what impact the introduction of genes into A. annua will have on the environment. In this study, phenotypic characterization, stress resistance, and gene flow of transgenic A. апnиa GYR and wild-type NON-GYR plants, which have similar survival competitiveness, were studied.

\section{Phenotypic characterization}

Transgenic A. апnua GYR and wild-type NON-GYR plants have similar growth and development processes, which can be divided into six stages: rejuvenation, vegetative, flower bud differentiation, squaring and early flowering, flowering, and grain-filling periods. Both varieties survived and there were no significant differences in the survival rate following transplantation in the field environment.

Both varieties of $A$. аnnua grew rapidly from August to September, and the plant height, crown width, and stem diameter were maximal between June 18 and October 9 in the late vegetative growth phase (Figure 5). There was no significant difference in plant height and crown width between the two varieties, but the stem diameter of NON-GYR plants was significantly higher than that of GYR plants. However, the growth trends of the two varieties were consistent.

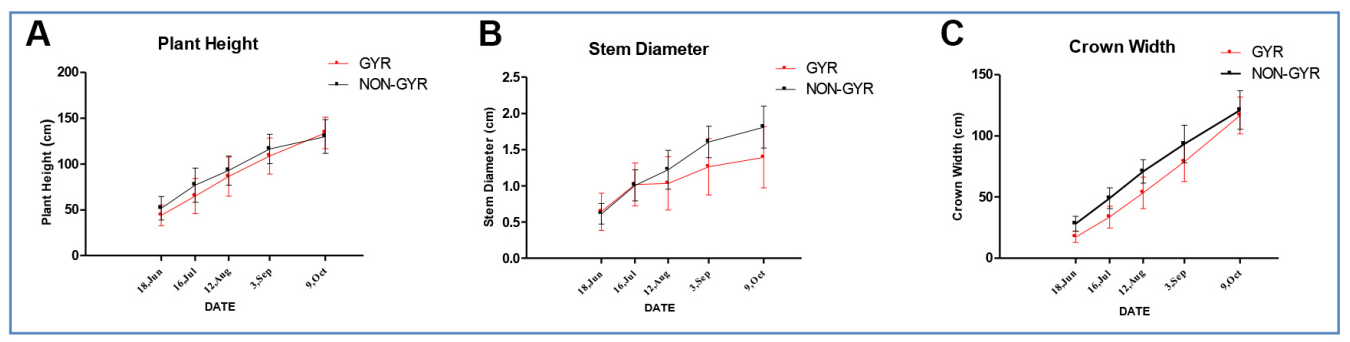

Figure 5. Two varieties of Artemisia annua grow faster between August and September. Plant height, crown width, and stem diameter peaked from June 18 to October 9 during the late vegetative growth of $A$. annua. A. Plant height; B. stem diameter; C. crown width.

Figure 6A shows that the aseptic germination rate was lowest in the three methods, and both distilled water and soil culture were higher than the aseptic way, that was up to $85 \%$. The germination rate of transgenic $A$. аnnиa plants was not similar to that of the wild type.

There was a significant difference in the dry weight of leaves from the two plant lines. The dry weight of GYR leaves was higher than that of NON-GYR leaves, which is probably due to the increased thickness of the GYR leaves. The leaf shape of the two $A$. annua varieties were three times pinnate toothed comb split, and the leaf morphology did not change. There was no significant difference in the 1000 -seed weight between plant lines (Figure 6).

Genetics and Molecular Research 15 (3): gmr.15038273 


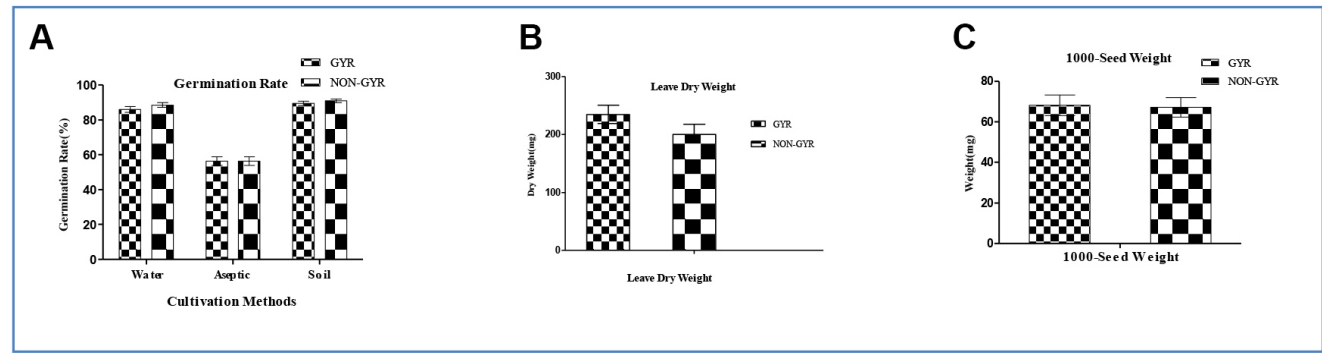

Figure 6. Agronomic characters of transgenic Artemisia annua. L. A. Germination rate; B. dry weight leaves; C. 1000 -seed weight.

\section{Stress resistance: salt stress}

\section{Leaf water content}

In order to compare the effects of salt stress, the leaf water content, as well as POD, MDA, and proline content was determined at different salt concentrations (Figure 7). The relative water content (RWC) of the two A. annua plants was quite high, within the range of 94 to $87 \%$. The RWC did not change with increasing $\mathrm{NaCl}$ concentration.

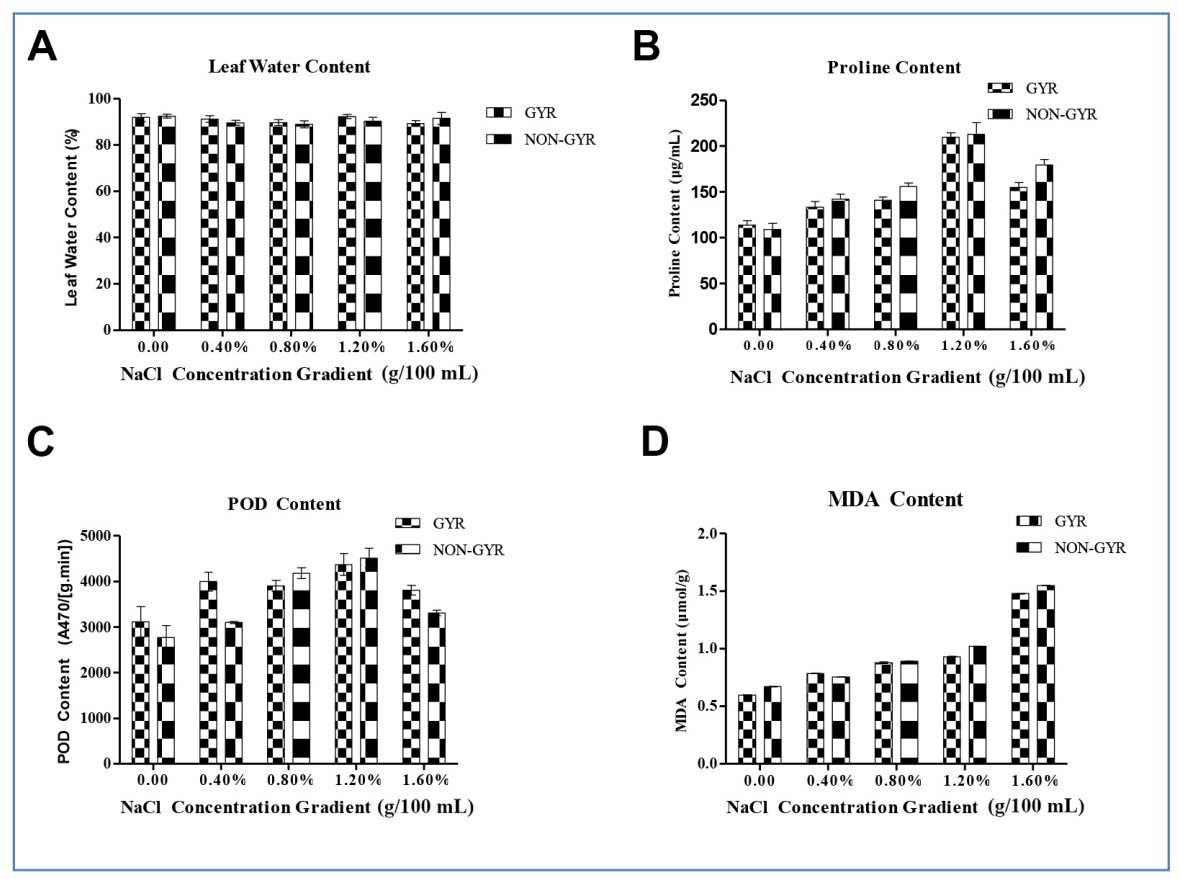

Figure 7. Leaf water content, proline content, POD content, and MDA content in the leaves of two Artemisia annua varieties following application of different $\mathrm{NaCl}$ concentrations. A. Leaf water content; B. proline content; C. POD content; D. MDA content.

Genetics and Molecular Research 15 (3): gmr.15038273 


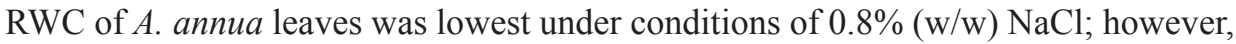
the RWC of GYR plants was higher than that of NON-GYR plants, and was significantly different in response to $1.6 \% \mathrm{NaCl}$. RWC followed a similar trend to leaf dry weight.

The two A. апnиa varieties showed some levels of physiological stress in response to salt treatment. Most leaves of $A$. аnnиa wilted to different degrees. There were no differences in the RWC of GYR and NON-GYR plants under salt stress.

POD levels in the leaves of the two A. апnи varieties first increased and then decreased as the concentration of $\mathrm{NaCl}$ rose. The POD level was highest at $1.2 \% \mathrm{NaCl}$, and the POD level of GYR plants was significantly lower than that of NON-GYR plants (up to $4600{ }^{\Delta} \mathrm{OD} \mathrm{mg}^{-1}$. FW. $\mathrm{min}^{-1}$ ). However, the POD level in GYR plants was significantly higher than that in NON-GYR plants when the concentration of $\mathrm{NaCl}$ was below $0.4 \%$.

\section{Proline content}

The proline content in leaves from the two varieties of $A$. annua continued to rise following an initial decline (Figure 7). Although the proline content in GYR leaves was higher than that in NON-GYR leaves in the absence of salt stress, this difference was not significant. This was in contrast to the results observed for proline levels in the presence of salt stress. The proline content of GYR leaves was lower than that of NON-GYR leaves at $0.4-1.6 \% \mathrm{NaCl}$, and the difference was significant when the $\mathrm{NaCl}$ concentration increased to $1.6 \%$.

Proline can improve the water absorption capacity of the plant, representing a selfregulating mechanism of plants under stress. However, the balance of the plants will be affected, causing the plant to wilt when the salt concentration exceeds its adjustment range.

\section{MDA content}

The MDA content gradually increased in the leaves of the two A. annua varieties; however, this difference was not significant, MDA content under $1.6 \% \mathrm{NaCl}$ stress was 2.5 times that under no stress conditions. The difference in the MDA content between the two $A$. апnиa leaves was significant $(\mathrm{P}<0.001)$. This may be associated with different degrees of membrane lipid peroxidation.

\section{Drought resistance}

Proline has multiple roles in plants. The present study focused on the levels of proline under PEG-simulated drought stress. Following treatment with different concentrations of PEG, proline levels were determined and are shown in Figure 8. The proline content in $A$. аппиа leaves only slightly increased as PEG concentration increased after 5 days.

In the absence of PEG stress, the proline content in GYR leaves was higher than that in NON-GYR leaves; however, this difference was not significant. After 15 days, the overall level of proline increased significantly under high PEG stress. The proline content in GYR leaves was higher than that in NON-GYR leaves at $300 \mathrm{~g} / \mathrm{L}$, although this was not significant $(\mathrm{P}>0.05), 2.7$ times of the concentration compared to the NON-GYR at $200 \mathrm{~g} / \mathrm{L}$. There was no obvious change in proline levels from 15 to 25 days. The level of proline in GYR leaves reached $532.598 \mu \mathrm{g} / \mathrm{g}$ at $300 \mathrm{~g} / \mathrm{L}$ PEG stress on day 25 , which was 7.97 -fold higher than that in the no stress condition. In NON-GYR plants, it reached 8.51-fold higher. The difference in

Genetics and Molecular Research 15 (3): gmr.15038273 
proline levels between the two varieties was not significant throughout the whole experimental period. It was inferred, therefore, that $A$. аппи may be adapted to dry environments.

Following 25 days' treatment with high concentrations of PEG $(300 \mathrm{~g} / \mathrm{L})$, the leaves had turned yellow, were curled, branches had shrunk, and the bottoms of the leaves had withered. However, at low concentrations of PEG (100-200 g/L) the growth of $A$. annua was not significantly affected, indicating that $A$. annua is a drought-tolerant plant.

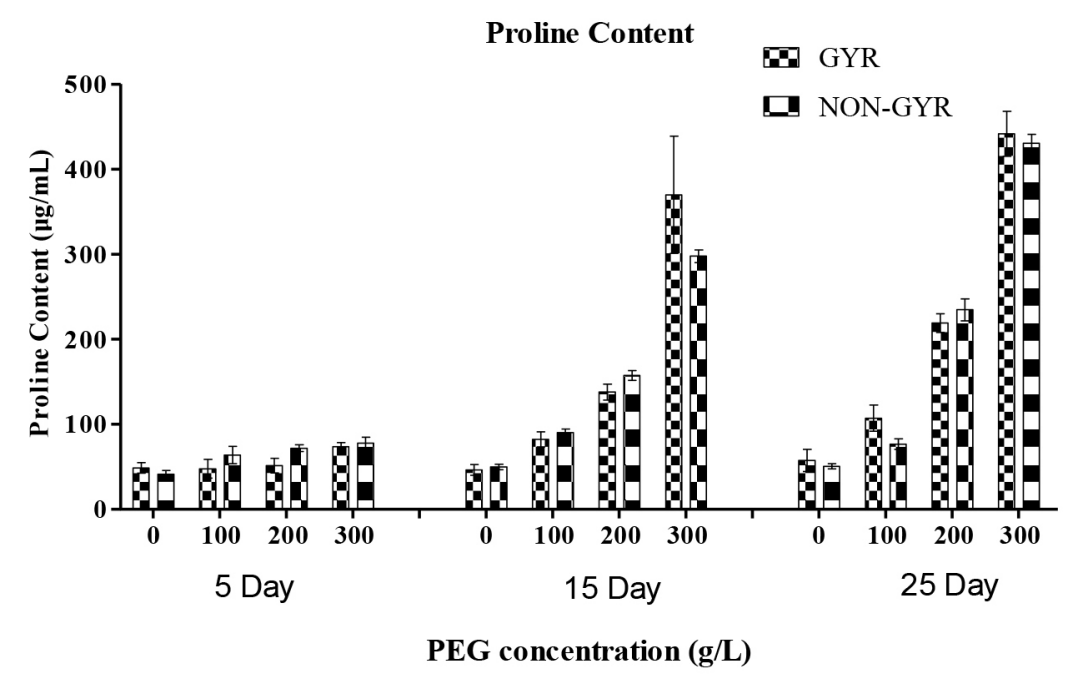

Figure 8. Proline content in the leaves of two Artemisia annua varieties under drought stress induced by application of different concentrations of PEG 6000 for different periods. 0: $0 \mathrm{~g} / \mathrm{L}$ PEG 6000; 100: $100 \mathrm{~g} / \mathrm{L}$ PEG 6000; 200: 200 g/L PEG 6000; 300: 300 g/L PEG 6000.

Figure 9 shows that in the absence of stress, the two $A$. апnиа plants performed similarly for plant height yield and compound leaf difference, and were both able to retain their balance.

With increasing PEG concentrations, the difference in plant height declined, as did the biomass and compound leaf difference. However, transgenic A. annua GYR plants did not show a stronger growth ability than NON-GYR plants under stress tolerance, and the difference was not significant. Plant height and compound leaf increment decreased when the concentration of PEG increased to $300 \mathrm{~g} / \mathrm{L}$.

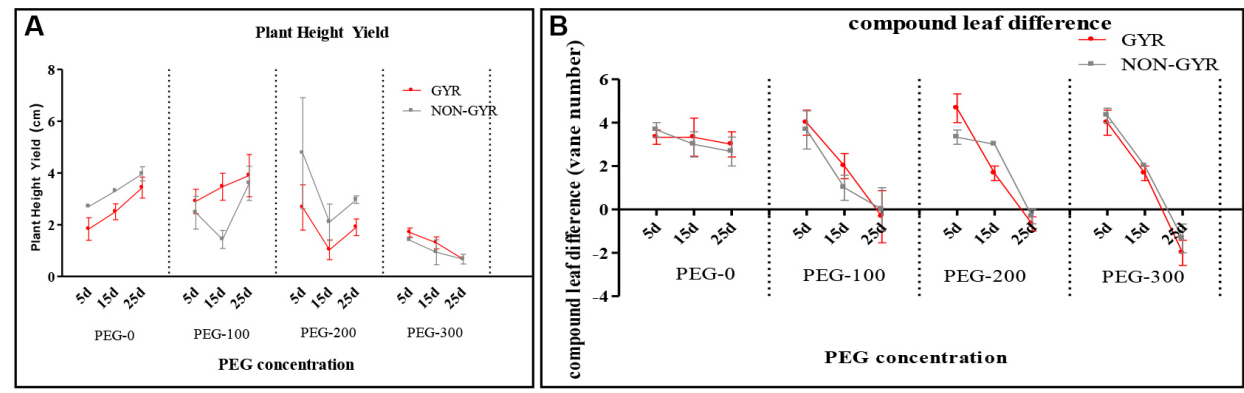

Figure 9. Plant height yield (A) and compound leaf (B) of the two Artemisia annua under drought stress by application of different concentrations of PEG 6000 for different periods $(\mathrm{d}=$ days $)$.

Genetics and Molecular Research 15 (3): gmr.15038273 
Two types of herbicides, paraquat and metolachlor, were used on $A$. аnnua seedlings (euphylla number $\geq 15$ ). Paraquat is non-selective and kills a wide range of plants. After spraying paraquat, all samples of transgenic and control plants were killed within $2 \mathrm{~h}$ (Figure $10 \mathrm{~A}$ and $\mathrm{B}$ ). Metolachlor is a selective herbicide and was sprayed before seed germination. No seeds of the two varieties of $A$. апnи a germinated while the seeds of the two varieties that were not sprayed with metolachlor successfully germinated and the seedlings grew well (Figure 10C and D). The performance of transgenic and control plants was similar, regardless of whether metolachlor was sprayed, which indicates that the transgenic and control plants responded similarly to the two common herbicides.
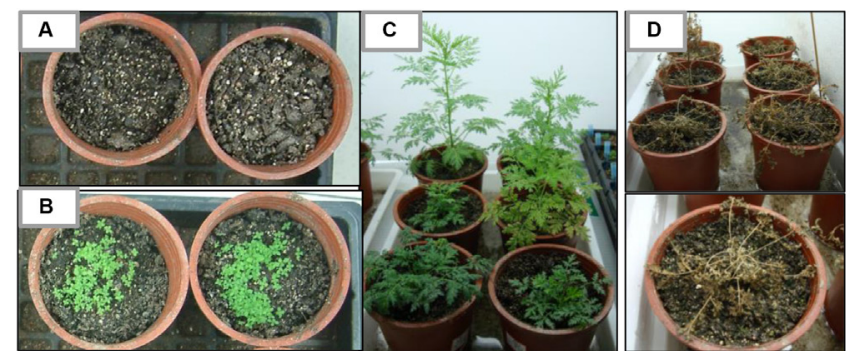

Figure 10. Growth pattern in response to the application of two types of herbicides, paraquat and metolachlor. A. Paraquat pre-treatment; B. after paraquat treatment; C. metolachlor pre-treatment; D. after metolachlor treatment.

\section{Wintering ability}

Seeds of the two A. аnnua lines were collected and sown so that their overwintering ability could be observed. Although the overwintering ability of GYR plants was slightly weaker than that of the NON-GYR plants, they still retained their vitality through the early winter $\left(2^{\circ}-5^{\circ} \mathrm{C}\right)$ and germinated successfully at the end of the winter (the lowest temperature was $-5^{\circ} \mathrm{C}$ ). The inserted gene is not believed to have an effect on the cold tolerance of the two A. annua lines.

\section{Gene flow}

It was detected that the average germination rate reached $82.7 \%$ (Table 1) when the seeds was harvest, which was relatively high and uniform in $A$. апnиa. Maybe because the seeds of these lines were new harvest seeds that is nutritionally adequate and has a higher germination rate.

It was found that $100 \mathrm{mg} / \mathrm{L}$ kanamycin had good selectivity for $A$. annua after seedling resistance screening between 25 at $150 \mathrm{mg} / \mathrm{L}$ (Wang and Yi, 2003; Rong et al., 2006).

One hundred A. аппиа seedlings were selected for culture on 1/2 MS solid medium. Three days later, the seedlings turned yellow at varying degrees. Six days later, the leaves began to wither at the edge, and whole seedlings decayed about 10 days later. It was concluded that the dead seedlings belonged to the NON-GYR line.

The seedlings (survival rate: Table 3) obtained by kanamycin resistance screening were transplanted into pots to keep the seedlings strong. Genomic DNA was extracted from 3-5 leaves of each A. annua plant after 20 days and was subjected to PCR (Table 4).

Genetics and Molecular Research 15 (3): gmr.15038273 
Figures 11 and 12 show that the gene frequency drift in transgenic A. annua GYR lines drastically declined with increasing distance. The transgene flow frequency of $\mathrm{C}-11$ was highest, 7-fold higher than G-3, which was the lowest frequency, maybe due to the effect of the north-easterly wind in the fall in Shanghai Qingpu District.

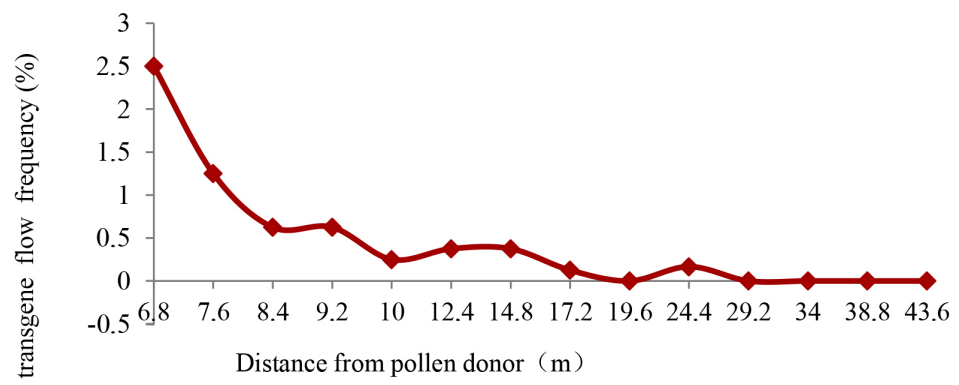

Figure 11. Transgene flow frequency chart.

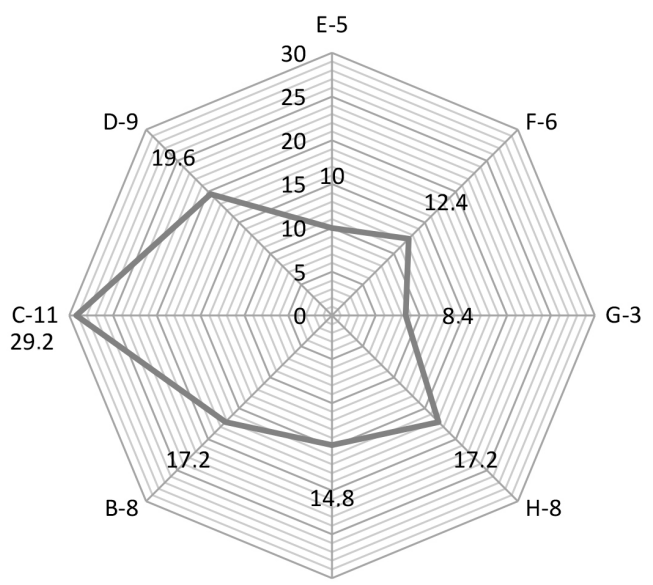

A-7

Figure 12. Top view of pollen drift. A-7: $14.8 \mathrm{~m}$; B-8: $17.2 \mathrm{~m}$; C-11: $29.2 \mathrm{~m}$; D-9: $19.6 \mathrm{~m}$; E-5: 10 m; F-6: 12.4 m. G-3: $8.4 \mathrm{~m}$; H-8: $17.2 \mathrm{~m}$.

The maximum gene flow frequency of $2.5 \%$ was obtained at $6.8 \mathrm{~m}$, as shown in Figure 11. It then declined, with increasing distance. It is easier to detect the gene flow at a 24.4-m distance of west which was wind direction. But at $29.2 \mathrm{~m}$, gene flow could not be detected in any direction in the environmental release trial.

\section{DISCUSSION}

A. annua is widely used in the treatment of malaria (Tu, 2009), and it also has potential benefit for some of the biggest health problems in the world. However, the artemisinin content of $A$. annua is very low [0.01-0.8\% dry/wt (dry weight/wet weight)], which has greatly limited its commercialization (Lei et al., 2011).

Genetics and Molecular Research 15 (3): gmr.15038273 
In recent years, there has been remarkable progress in the molecular regulation of artemisinin biosynthesis (Bouwmeester et al., 1999). Genes encoding several key enzymes involved in artemisinin biosynthesis, including ADS, AaWRKY1, CYP71AV1, and CPR have been cloned from A. апnиа (Chen et al., 2000; Liu et al., 2003; Martin et al., 2003). Based on the findings of previous studies, the transgenic $A$. апnи a variety GYR was generated, which has significantly increased artemisinin content (Zhang et al., 2009). Before commercialization, transgenic plants should be assessed in environmental release trials.

Although only short sequences of DNA are transferred during genetic engineering, the resulting phenotype can produce an organism that is novel to the existing network of ecological relationships, which might lead to weediness due to acquired tolerance to selective pressures (Martha, 2006). Recipient plants (being hardy, perennial, and competitive) could be high impact plants with regard to spread. Therefore, concerns about the stress tolerance and survival ability of transgenic plants must be addressed. In this study, environmental risk assessments of transgenic plants were undertaken. This result showed that there were no significant differences between transgenic $A$. апnи GYR plants and the conventional NON-GYR strain with respect to morphology (plant height, crown width, and stem diameter). Although the stem diameter of NON-GYR plants was significantly larger than that of GYR plants, the growth trend of the two $A$. annua varieties was consistent. The leaf dry weight of GYR plants was greater than that of NON-GYR plants, which was probably because the GYR leaves were thicker, and the leaf shape of the two varieties did not change. Other parameters were not significantly different between the two plant lines. Therefore, it could be inferred that the inserted gene did not alter the agronomic traits of $A$. апnиа.

Under salt stress, leaf water content, peroxidase level, and proline content in the leaves of the two varieties of $A$. апnиа first increased and then declined with increasing $\mathrm{NaCl}$ concentration. This may represent a self-regulating mechanism of the plant when under stress. Furthermore, the response mechanism of the two varieties under salt stress was similar. When the concentration of $\mathrm{NaCl}$ reached $1.6 \% \mathrm{w} / \mathrm{w}$, the difference was significant between transgenic A. аппиа GYR and NON-GYR plants. It may destroy the adjustment mechanism in plants under high concentration of salt, affecting its ability to adapt to changing conditions. At the same time, the difference in MDA content was extremely significant, which may be associated with different degrees of membrane lipid peroxidation. Research is ongoing to verify these differences.

The proline content of the two A. апnи plants was similar under PEG-simulated drought. Following PEG (300 g/L) treatment for 25 days, the content of proline increased dramatically, and on the bottom of the leaf, yellow spots, and curling appeared with shrinking branches. Therefore, the over-expressed gene did not increase $A$. annua weediness resistance, which was consistent with the results obtained for herbicides.

As $A$. аппиа is a cross-pollinated plant, intra-specific introgression is easily detected from plants in close proximity (Delabays et al., 2001; Bae et al., 2008). Therefore, gene flow between transgenic and conventional plants was assessed simultaneously.

Experimental data showed that the frequency of exogenous gene drift in the transgenic A. аnnиa plants declined rapidly as the distance from the pollen source increased. Even in the transgenic $A$. аnnua cultivation areas $(6.8 \mathrm{~m})$, the drift frequency of the non-transgenic $A$. annua plants was detected as being $2.5 \%$, when the location was downwind, and it decreased to $<1 \%$ at a distance of $8.4 \mathrm{~m}$. This may be due to the gradual decrease in transgenic pollen density in the air with increasing distance from the transgenic pollen source. Simultaneously,

Genetics and Molecular Research 15 (3): gmr.15038273 
the existence of a non-transgenic $A$. annua pollen source greatly diluted the transgenic pollen source, which could also lead to rapid decline in the gene drift frequency (Song et al., 2004).

Walklate et al. (2004) reported that setting the isolation distance can be effective at controlling gene flow in the model simulation experiments. In addition, some physical factors, including the movement of pollen, the settling rate of pollen particles, wind direction, wind speed, and the vertical dispersing coefficient, can also affect the frequency of gene drift (Jiang et al., 2010a).

Gene flow frequency was unequal in different directions, which suggests this is an effective method to limit gene drift. Genetically modified $A$. annua can be cultivated downwind or be isolated using an isolation zone. Moreover, the flowering period of transgenic and non-transgenic $A$. апnиа plants can be adjusted, so that the two plants will not flower synchronously, which can greatly reduce the possibility of gene drift occurring.

In this study, transgenic $A$. Annua plants were cultivated as a pollen source in a circle with a $6 \mathrm{~m}$ in diameter; however, it is not clear whether this had a significant effect on gene flow frequency. Gustafson et al. (2005) reported that the size of the pollen source had little effect on gene flow frequency in the field using a model of wheat gene flow frequency. Furthermore, no significant effect on gene flow frequency was detected from the test carried out by Rong (2006). Nevertheless, for large-scale commercial cultivation of transgenic $A$. апnиa, the use of physical and biological isolation is needed to prevent the spread of pollen.

\section{Conflicts of interest}

The authors declare no conflict of interest.

\section{ACKNOWLEDGMENTS}

Research supported by the Key Technologies R\&D Program of Shanghai Agricultural Commission (grant \#2015-4-3) and the Shanghai Academy of Agricultural Sciences [grant \#2012(09)].

\section{REFERENCES}

Bae TW, Vanjildorj E, Song SY, Nishiguchi S, et al. (2008). Environmental risk assessment of genetically engineered herbicide-tolerant Zoysia japonica. J. Environ. Qual. 37: 207-218. http://dx.doi.org/10.2134/jeq2007.0128

Bouwmeester HJ, Wallaart TE, Janssen MHA, van Loo B, et al. (1999). Amorpha-4.11-diene synthase catalyses the first probable step in artemisinin biosynthesis. Phytochemistry 52: 843-854. http://dx.doi.org/10.1016/S00319422(99)00206-X

Chen D, Ye H and Li G (2000). Expression of a chimeric farnesyl diphosphate synthase gene in Artemisia annua L. transgenic plants via Agrobacterium tumefaciens-mediated transformation. Plant Sci. 155: 179-185. http://dx.doi. org $/ 10.1016 / \mathrm{S} 0168-9452(00) 00217-\mathrm{X}$

Conner AJ, Glare TR and Nap JP (2003). The release of genetically modified crops into the environment. Part II. Overview of ecological risk assessment. Plant J. 33: 19-46.http://dx.doi.org/10.1046/j.0960-7412.2002.001607.x

Delabays N, Simonnet X and Gaudin M (2001). The genetics of artemisinin content in Artemisia annua L. and the breeding of high yielding cultivars. Curr. Med. Chem. 8: 1795-1801.http://dx.doi.org/10.2174/0929867013371635

Gustafson DI, Horak MJ, Rempel CB, Metz SG, et al. (2005). An empirical model for pollen-mediated gene flow in wheat. J. Crop Sci 45: 1286-1294. http://dx.doi.org/10.2135/cropsci2004.0137

Hunting WM, Marcel G and Esselen WB (1959). New method for peroxidase determination. Anal. Chem. 31: 143-144. http://dx.doi.org/10.1021/ac60145a034

Hutchison WD, Burkness EC, Mitchell PD, Moon RD, et al. (2010). Areawide suppression of European corn borer with Bt maize reaps savings to non-Bt maize growers. Science 330: 222-225. http://dx.doi.org/10.1126/science.1190242

Genetics and Molecular Research 15 (3): gmr.15038273 
Jia S and Peng Y (2002). GMO biosafety research in China. Environ. Biosafety Res. 1: 5-8. http://dx.doi.org/10.1051/ ebr/2002999

Jiang DLG, Yang L, Huang JH, Chen J, et al. (2010a). Study on gene flow of transgenic rice. Biotechnol. Bull 6: 95-99.

Jiang LX, Liu H, Wang J, Tanl F, et al. (2010b). Characterization and comparison of three transgenic Artemisia annua varieties and wild-type variety in environmental release trial. J. Med. Plants Res. 4: 2719-2728.

Lai KL and Lui LF (1988). Increased plant regeneration frequency in water-stressed rice tissue cultures. J. Crop. Sci. 57: 553-557. http://dx.doi.org/10.1626/jcs.57.553

Lawlor DW (1970). Absorption of polyethylene glycols by plants and their effects on plant growth. New Phytol. 69: 501513. http://dx.doi.org/10.1111/j.1469-8137.1970.tb02446.x

Lei CY, Ma DM, Pu GB, Qiu XF, et al. (2011). Foliar application of chitosan activates artemisinin biosynthesis in Artemisia annua L. Ind. Crops Prod. 33: 176-182. http://dx.doi.org/10.1016/j.indcrop.2010.10.001

Lei Y, Yin C, Ren J and Li C (2007). Effect of osmotic stress and sodium nitroprusside pretreatment on proline metabolism of wheat seedlings. Biol. Plant. 51: 386-390. http://dx.doi.org/10.1007/s10535-007-0082-0

Liu Y, Ye HC, Wang H and Li GF (2003). Molecular cloning, Escherichia coli expression and genomic organization of squalene synthase gene from Artemisia annua. Acta Bot. Sin. 45: 608-613.

Lu X, Qian S, Ling Z, Fang Z, et al. (2013). Promotion of artemisinin biosynthesis in transgenic Artemisia annua by overexpressing ADS, CYP71AV1 and CPR genes. Ind. Crops Prod. 49: 380-385. http://dx.doi.org/10.1016/j. indcrop.2013.04.045

Martha M (2006). Assessment of environmental impacts of genetically modified plants. Implementation of the Biosafety Protocol Development of Assessment Bases. BfN. Bonn.[http://www.bfn.de]

Martin VJJ, Pitera DJ, Withers ST, Newman JD, et al. (2003). Engineering a mevalonate pathway in Escherichia coli for production of terpenoids. Nat. Biotechnol. 21: 796-802. http://dx.doi.org/10.1038/nbt833

Qinghaosu Antimalaria Coordinating Research Group (1979a). Antimalaria studies on Qinghaosu. Chin. Med. J. 92: 811-816.

Qinghaosu Antimalaria Coordinating Research Group (1979b). Research Artemisinin Antimalarial Drugs. Chin. Pharm. J. 14: 49-53.

Romeis J, Shelton AM, Kennedy GG, Hellmich RL, et al. (2008). The present and future role of insect-resistant genetically modified maize in IPM. In: Integration off insect-resistant genetically modified crops within IPM Programs. Vol. 5. Progress in Biological 963 Control. Springer, The Netherlands, 119-158.

Rong J (2006). Pollen-mediated gene flow and its modeling in rice (Oryza sativa L.). D.S.H: Fudan University.

Rong J, Song Z, Su J, Xia H, et al. (2006). Low frequencies of transgene flow between Bt/CpTI rice and their nontransgenic counterparts under alternating cultivation. Biodivers. Sci. 14: 309-314.

Shi WM, Xu WF, Li SM, Zhao XQ, et al. (2010). Responses of two rice cultivars differing in seedling-stage nitrogen use efficiency to growth under low-nitrogen conditions. Plant Soil 326: 291-302. http://dx.doi.org/10.1007/s11104-009$\underline{0007-0}$

Song ZP, Lu BR and Chen JK (2004). Pollen flow of cultivated rice measured under experimental conditions. J. Biodiver. Conserv. 13: 579-590. http://dx.doi.org/10.1023/B:BIOC.0000009491.24573.1d

Summart J, Thanonkeo P, Panichajakul S, Prathepha P, et al. (2010). Effect of salt stress on growth. inorganic ion and proline accumulation in Thai aromatic rice, Khao Dawk Mali 105, callus culture. Afr. J. Biotechnol. 9: 142-152.

Tu YY (2009). Artemisia annua and artemisinins drugs. Chemical Industry Press. Beijing.

Walklate PJ, Hunt JCR, Higson HL and Sweet JB (2004). A model of pollen-mediated gene flow for oilseed rape. Proc. Biol. Sci. 271: 441-449. http://dx.doi.org/10.1098/rspb.2003.2578

Wang T, Shen Q, Lu X, Jiang WM, et al. (2012). Inheritance Analysis of CYP71AV1 and CPR Genes in Progeny of Transgenic Artemisia annua L. J. Shanghai Jiaotong Univ. (Agric. Sci.). 30: 8-14.

Wang ZX and Yi ZL (2003). The Application of Kanamycin in Transgenic Plants and the Biosafety Assessment of Kanr Gene. China. Biotechnology 23: 9-13.

Weathers PJ, Elkholy S and Wobbe K (2006). Artemisinin: the biosynthetic path way and its regulation in Artemisia annua, a terpenoid-rich species. In Vitro Cell. Dev. Biol. Plant 42: 309-317. http://dx.doi.org/10.1079/IVP2006782

Zhang L, Jing F, Li F, Li M, et al. (2009). Development of transgenic Artemisia annua (Chinese wormwood) plants with an enhanced content of artemisinin, an effective anti-malarial drug, by hairpin-RNA-mediated gene silencing. Biotechnol. Appl. Biochem. 52: 199-207. http://dx.doi.org/10.1042/BA20080068

Genetics and Molecular Research 15 (3): gmr.15038273 